\title{
BETWEEN THE CAPTURE AND DISSEMINATION OF DATA: THE IMPORTANCE OF THE DNV AND ITS ADEQUATE COMPLETION
}

\author{
Maria do Carmo Andrade Duarte de Farias ${ }^{1}$, Karla Maria Duarte Silva Oliveira ${ }^{2}$, \\ Alcides da Silva Diniz², Paula Christianne Gomes Gouveia Souto Maia ${ }^{4}$, \\ Kennia Sibelly Marques de Abrantes ${ }^{5}$, Luiz Carlos de Abreu ${ }^{5}$
}

\begin{abstract}
Introduction: the Information System on Live Birth (SINASC) aims to receive and disseminate information about the live births, the mothers, the gestation, birth, of the newborn; taking into consideration that the information about the live births of a country or a particular region is fundamental, because thebirths are part of the composition of variousdemographic and epidemiological indicators, such as the rates of infant mortality, low birth weight, birth rates and fecundity. Objective: this research aimed to compare the data contained in the DNV (White duplicate) compared to the disclosed in the SINASC/DATASUS, in the municipality of Cajazeiras, PB (2006-2010). Method: it is a descriptive study, by means of revising the 3972 DNV from 2006 to 2010, archived in the sector of Epidemiologic Vigilance, and also the data disclosed in the SINASC, relating to the mothers residing in the referred municipality. Results: it was perceived a significant flaw in the completion of the DNV and ambiguity between the SMS and DATASUS data, thereby jeopardizing the reliability and questioning the precision and completeness of the registers of this information system compared to the SMS ones. Thereby, in addition to the flaws in the adequate completion in of the DNV at the birth place, there were flaws in the electronic typing of the data. Conclusion: thus, the results point to a need of the Municipal Health Department to promote training and guidance for the person responsible for the completion of the DNV and the electronic typing of the system, in order to achieve a total and correct completion of all the items of the DNV; emphasizing the importance of this document and its integral completion.
\end{abstract}

Key words: information systems, declaration of live birth, health status indicators.

\section{INTRODUCTION}

The Information System on Live Birth proposes to capture and disseminate information about the live births, the mothers, the gestation, the parturition and the new born. Thereby, this system provides conditions to identify the characteristics of the newborn at birth, mother's age, and furthermore, allows comparisons and temporal analysis of the information, among others. So, from an epidemiologic aspect, the information derived from the SINASC allows a comprehensive analysis about the maternal-infant health, for instance the comparative demographic research by maternal age, indicators of the coverage of antenatal consultations.

Any information system starts with the trustworthy and responsible capture of data, so that a compatible and trustworthy characte-rization of what is aimed to demonstrate. In the case of the SINASC, the attentive and accurate completion of the DNV is of great importance, as this document is a basis for the system's information, besides being a primary subsidy for the civil register.

The person responsible for the completion of the DNV must be properly trained and instructed about the importance of answering all the information, precisely, and do not measure efforts so that all the variables are completed, avoiding as much as possible ignoredor not informed data.

In this regard, the Health Department recommends that the person previously trained for this purpose is a nurse, member of a nursing team, doctor or Professional from the administrative area $^{1}$.

1 Nurse, PhD in Nursing from UFC, Post-doctorate degree from the Faculty of Medicine ABC, Santo André, SP.

2 Nurse. Master in Science in Nursing from the Federal University of Paraíba. Member of the research group about men's health.

3 Doctor. Master of Science in Ophthalmology from the Medical Faculty of Ribeirão Preto (1985). PhD in Nutrition from the Federal University of Pernambuco (1997). Post-doctorate degree from the Prince Leopold Institute of Tropical Medicine (2003-2004). Associate Professor of the Federal University of Pernambuco, collaborator of the Investigation Center in Micro-nutrients (UFPB), of the Maternal Infantile Institute of Pernambuco, and ad hoc consultant of UNICEF.

4 Doctor.Specialist in Family and Labourers Health.Professor of the Federal University of Campina Grande/CFP, Cajazeiras, PB.

5 Laboratório de Delineamento de Estudos e Escrita Científica. Departamento de Saúde da Coletividade. Faculdade de Medicina do $A B C$.

Corresponding author: carmofarias@hotmail.com

Suggested citation: Farias MCAD, et al. Between the capture and dissemination of data: the importance of the DNV and its adequate completion, Journal of Human Growth and Development, 24(2):150-156

Manuscript submitted Aug 01 2013, accepted for publication Dec 282013. 
Various studies have investigated the reliability and validity of the DNV as an instrument to assess the health of the maternal and infant population, in view of the necessary precision in its completion, as well as in the registration of data in the SUS informatics bank ${ }^{2,3}$.

So, the aimed is to compare the data contained in the DNV ( White duplicate) with the data registered in the SINASC, disseminated in the DATASUS, related to the municipality of Cajazeiras, PB, in the period from 2006 to 2010.

\section{METHODS}

A descriptive study was carried out, by the means of a revision of II the DNV from 2006 to 2010 archived in paper (White duplicate) in the Epidemiological Surveillance (VE) of the municipality of Cajazeiras, PB, totalizing 3972 DNV. This municipality has a public maternity hospital which besides assisting its resident population, in the pregnant and puerperal phase, it also assists women from surrounding towns, since Cajazeiras is a central city of the "sertão" region of the sate of Paraiba, and where is located the IX Regional Health administration department of the State of Paraíba. In the referred maternity hospital, an average of 04 deliveries is carried out a day. Cajazeiras-PB has a territorial area of $566 \mathrm{~km}^{2}$, and an estimated population of 58.443 inhabitants, according to the data presented by the Brazilian Institute of Geography and Statistics ${ }^{4}$. The data collection was carried out directly from the archives of the IX Regional Health Management Department of Cajazeiras, PB in the sector of Epidemiological Surveillance, in the Municipal
Health Department. For this, an instrument was built, containing spaces for the literal transcription of all the registers contained in the DNV. The period of data collection extended from June 2009 to February 2011, in interleaved intervals. The collection instruments were numbered and coded for the use of the Statistical Package for the Social Sciences (SPSS). The data bank was typed by 2 people, in separate, and checked by two others who did not type the databank. Considering the births from mothers who resided in the referred municipality, the total of births per year, number of antenatal consultations, type of births, ignored and not informed data, were investigated. The information obtained from the DNV was compared to those published by the DATASUS. The data is presented in tables, with frequency and percentage. The research was approved by the Committee for Ethics in Research, from the Center of Health and Rural Technology, UFCG , Patos PB, under the protocol number $114 / 2009$ on $01 / 06 /$ 2009. The initial proposal of this research was the historical series 2005-2009. However, in the SMS (Municipal Health Department) the 2005 DNV were not found, so for this reason the 2006-2010 DNV were analyzed.

\section{RESULTS}

DNV of the municipality of Cajazeiras-PB: information compared to the SINASC, DATASUS. - Live births, antenatal consultations and types of birth.

In the table 1 , the data demonstrates the frequency of live births, revealing a percentage of $21,8 \%$ in the year of $2006,20,9 \%$ in 2007 , $20,2 \%$ in $2008,17,5 \%$ in 2009 and $19,6 \%$ in 2010 .

Table 1: Distribution of Live Births according to theyear of register of the DNV.Cajazeiras-PB, 2006-2010

$\begin{array}{cr}\text { YEAR OF REGISTER } & \mathbf{n} \\ 2006 & 864 \\ 2007 & 830 \\ 2008 & 804 \\ 2009 & 697 \\ 2010 & 777 \\ \text { Total } & \mathbf{3 9 7}\end{array}$

$\begin{array}{cc}\mathbf{n} & \% \\ 864 & 21,8 \\ 830 & 20,9 \\ 804 & 20,2 \\ 697 & 17,5 \\ 777 & 19,6 \\ 972 & \mathbf{1 0 0}\end{array}$

source: DNV. SMS Cajazeiras-PB: 01 January 2006 a 31 December 2010.

However, although the data of the SINASC show a decrease in registers of Live Births, year after year from 2007 to 2010, there was a significant increase from 2006 to 2007. Besides this, the registers of Live Births in the municipality of Cajazeiras, disseminated in this information System, are bigger than those of the SMS, in all years, except 2006 (Table 2)

Table 2: Distribution of births by mother's residence by year of birth, according to the place of occurrence.Cajazeiras-PB, 2006-2010

\begin{tabular}{|c|c|c|c|c|c|c|}
\hline $\begin{array}{l}\text { IDENTIFICATION OF THE OCCURENCE/ } \\
\text { SOURCE OF INFORMATION }\end{array}$ & & $\begin{array}{c}2006 \\
n\end{array}$ & $\begin{array}{c}2007 \\
n\end{array}$ & $\begin{array}{c}2008 \\
n\end{array}$ & $\begin{array}{c}2009 \\
n\end{array}$ & $\begin{array}{c}2010 \\
n\end{array}$ \\
\hline Hospital & $\begin{array}{l}\text { SMS } \\
\text { SINASC }\end{array}$ & $\begin{array}{l}863 \\
674\end{array}$ & $\begin{array}{l}828 \\
909\end{array}$ & $\begin{array}{l}804 \\
869\end{array}$ & $\begin{array}{l}697 \\
799\end{array}$ & $\begin{array}{l}777 \\
871\end{array}$ \\
\hline Other establishments & SMS & - & 1 & - & - & - \\
\hline Domicile & $\begin{array}{c}\text { SINASC } \\
\text { SMS }\end{array}$ & $\begin{array}{l}1 \\
1\end{array}$ & $\begin{array}{l}1 \\
1\end{array}$ & $\begin{array}{l}- \\
-\end{array}$ & $\begin{array}{l}3 \\
-\end{array}$ & - \\
\hline & SINASC & - & 1 & . & - & - \\
\hline TOTAL & $\begin{array}{l}\text { SMS } \\
\text { SINASC }\end{array}$ & $\begin{array}{l}864 \\
675\end{array}$ & $\begin{array}{l}830 \\
911\end{array}$ & $\begin{array}{l}804 \\
869\end{array}$ & $\begin{array}{l}697 \\
802\end{array}$ & $\begin{array}{l}777 \\
871\end{array}$ \\
\hline
\end{tabular}

Source: DNV. SMS Cajazeiras-PB: 01 January 2006 to 31 December 2010. SINASC/DATASUS, 2006-201055. 
The data presented in table 3 demonstrates the distribution of the mothers according to the year of the register of the DNV versus the number of antenatal consultations and the type of birth.

In the temporal series investigated, from an universe of 3914 DNV, 2204 (56,3\%) mothers had less than 7 consultations; and $1710(43,7 \%)$ more than 7 consultations. In general, it is noticed that there was not an increase in the antenatal coverage between the years of 2006 and 2009. Between the years of 2006 and 2010 there was anincrease of $4,9 \%$ in the realization of 7 or more consultations; the years of 2006 and 2008 presented the same percentage $(43,8 \%)$.

Table 3: Distribution of mothers investigated according to the year of register of DNV accordingly to the number of antenatal consultations, Cajazeiras-PB, $2006-2010$.

\begin{tabular}{|c|c|c|c|c|c|c|c|}
\hline \multirow{3}{*}{ Year of registration } & \multirow{3}{*}{$\begin{array}{c}\text { Source of } \\
\text { Information }\end{array}$} & \multirow{2}{*}{\multicolumn{2}{|c|}{ Total }} & \multicolumn{4}{|c|}{ Number of antenatal consultations } \\
\hline & & & & \multicolumn{2}{|c|}{ Less than 7} & \multicolumn{2}{|c|}{ 7or + } \\
\hline & & $\mathbf{n}$ & $\%$ & $\mathbf{N}$ & $\%$ & $\mathbf{n}$ & $\%$ \\
\hline \multirow[t]{2}{*}{2006} & SMS & 859 & 100 & 483 & 56,2 & 376 & 43,8 \\
\hline & SINASC & 669 & 100 & 371 & 55,5 & 298 & 44,5 \\
\hline \multirow[t]{2}{*}{2007} & SMS & 818 & 100 & 495 & 60,5 & 323 & 39,5 \\
\hline & SINASC & 895 & 100 & 517 & 57,8 & 378 & 42,2 \\
\hline \multirow[t]{2}{*}{2008} & SMS & 796 & 100 & 447 & 56,2 & 349 & 43,8 \\
\hline & SINASC & 852 & 100 & 468 & 54,9 & 384 & 45,1 \\
\hline \multirow[t]{2}{*}{2009} & SMS & 683 & 100 & 390 & 57,1 & 293 & 42,9 \\
\hline & SINASC & 781 & 100 & 427 & 54,7 & 354 & 45,3 \\
\hline \multirow[t]{2}{*}{2010} & SMS & 758 & 100 & 389 & 51,3 & 369 & 48,7 \\
\hline & SINASC & 854 & 100 & 416 & 48,7 & 438 & 51,3 \\
\hline \multirow[t]{2}{*}{ Total* } & SMS & 3914 & 100 & 2204 & 56,3 & 1710 & 43,7 \\
\hline & SINASC & 4051 & 100 & 2199 & 54,3 & 1852 & 45,7 \\
\hline
\end{tabular}

Source: DNV. SMS Cajazeiras-PB: 01 January 2006 to 31 December 2010; SINASC ${ }^{5}$.

* Excluded DNV with ignored data.

With regard to the type of birth according to the years of registers of the DNV, in table 4
$56,6 \%$ of caesareans and $43,4 \%$ of vaginal births are verified, in the universe of 3950 live births.

Table 4: Distribution of the mothers investigated according to the year of register of the DNV accordingly to the type of birth, Cajazeiras-PB, 2006 - 2010

\begin{tabular}{|c|c|c|c|c|c|c|c|}
\hline \multirow{3}{*}{ Year of register } & \multirow{3}{*}{$\begin{array}{l}\text { Source of } \\
\text { information }\end{array}$} & \multirow{2}{*}{\multicolumn{2}{|c|}{ Total }} & \multicolumn{4}{|c|}{ Type of birth } \\
\hline & & & & \multicolumn{2}{|c|}{ Vaginal } & \multicolumn{2}{|c|}{ Caesarean } \\
\hline & & $\mathbf{n}$ & $\%$ & $\mathbf{n}$ & $\%$ & $\mathbf{n}$ & $\%$ \\
\hline \multirow[t]{2}{*}{2006} & SMS & 861 & 100 & 441 & 51,2 & 420 & 48,8 \\
\hline & SINASC & 672 & 100 & 330 & 49,9 & 342 & 50,1 \\
\hline \multirow[t]{2}{*}{2007} & SMS & 826 & 100 & 359 & 43,5 & 467 & 56,5 \\
\hline & SINASC & 907 & 100 & 364 & 40,1 & 543 & 59,9 \\
\hline \multirow[t]{2}{*}{2008} & SMS & 796 & 100 & 332 & 41,7 & 464 & 58,3 \\
\hline & SINASC & 862 & 100 & 337 & 39,9 & 525 & 60,1 \\
\hline \multirow[t]{2}{*}{2009} & SMS & 691 & 100 & 284 & 41,1 & 407 & 58,9 \\
\hline & SINASC & 796 & 100 & 309 & 38,8 & 487 & 61,2 \\
\hline \multirow[t]{2}{*}{2010} & SMS & 776 & 100 & 297 & 38,3 & 479 & 61,7 \\
\hline & SINASC & 870 & 100 & 305 & 35,1 & 565 & 64,9 \\
\hline Total* & $\begin{array}{c}\text { SMS } \\
\text { SINASC }\end{array}$ & $\begin{array}{l}3950 \\
4107\end{array}$ & $\begin{array}{l}100 \\
100\end{array}$ & $\begin{array}{l}1713 \\
1645\end{array}$ & $\begin{array}{l}43,4 \\
40,0\end{array}$ & $\begin{array}{l}2237 \\
2462\end{array}$ & $\begin{array}{l}56,6 \\
60,0\end{array}$ \\
\hline
\end{tabular}

Source: DNV. SMS Cajazeiras-PB: 01 January 2006 to 31 of December 2010; SINASC ${ }^{5}$.

* Excluded DNV with ignored data.

\section{- Ignored and not informed data}

The table 5 presents the distribution of the variables which contained ignored and not informed data in the completion of the DNV (White duplicate) archived in the Epidemiological surveillance, Municipal Health department (SMS) and also registered in the SINASC, regarding the municipality of Cajazeiras - PB, in the years 2006 - 2010. 
Table 5: Distribution of the variables with ignored (I) or not informed (NI) data. Cajazeiras-PB, 2006-2010

\begin{tabular}{|c|c|c|c|c|c|c|}
\hline \multicolumn{2}{|l|}{$\begin{array}{l}\text { VARIABLES*/ } \\
\text { SOURCE OF INFORMATION }\end{array}$} & 2006 & 2007 & 2008 & 2009 & 2010 \\
\hline \multirow{2}{*}{ Maternal Age (NI) } & SMS & - & - & 3 & - & 2 \\
\hline & SINASC & - & - & - & - & - \\
\hline Marital status (I) & SMS & 11 & 4 & 9 & 9 & 11 \\
\hline SINASC & 9 & 11 & 13 & 10 & 13 & \\
\hline \multirow[t]{2}{*}{ Schooling (I) } & SMS & 12 & 9 & 7 & 7 & 12 \\
\hline & SINASC & 9 & 12 & 15 & 11 & 16 \\
\hline \multirow[t]{2}{*}{ Occupation (NI) } & SMS & 5 & - & 2 & 3 & 3 \\
\hline & SINASC & & Is $n$ & ntioned & SINASC & \\
\hline Precedence (I) & $\begin{array}{ll}\text { SMS } \\
\text { SINASC }\end{array}$ & 2 & - & $\stackrel{1}{1}$ & SINASC & 1 \\
\hline Previous gestations (NI) & $\begin{array}{l}\text { SMS } \\
\text { SINASC }\end{array}$ & 3 & 4 & $\begin{array}{c}4 \\
\text { ntioned }\end{array}$ & SINASC & 6 \\
\hline \multirow{2}{*}{ Duration of gestation(I) } & SMS & 4 & 11 & 16 & 9 & 17 \\
\hline & SINASC & 1 & 11 & 15 & 8 & 15 \\
\hline \multirow[t]{2}{*}{ Type of birth (I) } & SMS & 3 & 4 & 8 & 6 & 1 \\
\hline & SINASC & 3 & 4 & 7 & 6 & 1 \\
\hline \multirow{2}{*}{$\begin{array}{l}\text { Number of antenatal } \\
\text { consultations (I) }\end{array}$} & & & & & & \\
\hline & $\begin{array}{ll}\text { SMS } \\
\text { SINASC }\end{array}$ & $\begin{array}{l}5 \\
3\end{array}$ & 12 & 8 & 14 & 19 \\
\hline \multirow[t]{2}{*}{ Weight of the newborn (NI) } & SMS & 2 & 8 & 1 & - & - \\
\hline & SINASC & - & 1 & - & - & - \\
\hline
\end{tabular}

Source: DNV. SMS Cajazeiras-PB: 01 january 2006 to 31 December 2010. SINASC/DATASUS, 2006-20105.

\section{DISCUSSIONS}

Observing the findings of the Table 1 it is observed a decrease in the registration of live births in the years 2006 to 2009 , with a considerable decrease $(2,7 \%)$ from 2008 to 2009 , followed by an increase $(2,1 \%)$ from 2009 to 2010 . However, taking as a basis the registration of live births in 2006, there was a decrease in relation to the other years; highlighting the reduction of $4,3 \%$, comparing to the percentages of 2006 and 2009. These findings confirm the information published by the IBGE ${ }^{6}$, which is, in the last years, there has been a tendency of reduction in the índex of fertility, in Brazil.

According to the DATASUS, during the periodof 2006 to 20104128 children were born. However, for this same period, the data archived in the SMS indicates the birth of 3972 children. Thus, the births of 189 live born in 2006are not listed in the SINASC, in the municipality at issue; and in the other years, the data is above of the number of occurrences of live born in mothers resident in Cajazeiras, PB, according to the data of the SMS (Table 2)

According to the Table 3, in the investigated temporal series, from the universe of 3914 DNV, $2204(56,3 \%)$ mothers had attended less than 7 consecutive consultations; and 1710 (43,7\%) above 7 consultations. In general, it is noticeable that there was no increase in the antenatal coverage between the years of 2006 and 2009 . And the years of 2006 to 2008 presented the same percentage $(43,8 \%)$.

Thus, the studied municipality, the percentage of mothers who had above 7 consultations, except for the Northeast Region $(41,2 \%)$, is smaller than those indicated for : Paraíba $(50,25 \%)$ and João Pessoa (Capital)
$(56,2 \%)$, in the years $2006-2009$, according to the Indicators of Antenatal Coverage ${ }^{7}$.

By consulting the DATASUS was observed a discrepancy between the percentage of this research and those informed for the municipality of Cajazeiras-PB, found in the SINASC (Table 3). In the years 2006 to 2009, respectively, in this information system is shown the following percentages for the accomplishment of 7 or more antenatal consultations:44,5\%, 42,2\%, 45,1\%, $45,3 \%, 51,3 \%$. Even if the data is overestimated, it does not reveal the expected adhesion to the antenatal consultations, and does not represent a satisfactory health indicator.

With regard to the type of birth according to the years of register of the DNV, in the Table 4 is verified $56,6 \%$ of caesareandeliveries and $43,4 \%$ vaginal deliveries, from an universe of 3950 live births. Contrasting what is evidenced in the percentage of vaginal births, year after year, there was an increase in the incidence of caesareans. Taking as a reference the year of 2006, comparing it to the other investigated years, the percentage of cesareans rose in $7,7 \%, 9,5 \%, 10,1 \%$ and $12,9 \%$ respectively, 2006-2007, 2006-2008, 2006-2009 and 2006-2010.

Once more, the findings of the SMS diverge from the ones disclosed by SINASC, regarding the proportion of caesareans for live born (20062009), since in the Northeastern Region, Paraíba, JoãoPessoa and Cajazeiras, respectively, the percentage of caesareans were $37,9 \%, 45,9 \%$, 57,73 and $58,2^{5,7}$

As for the data of the SINASC/DATASUS (Table 4) an increase was also observed in the informed percentages for the municipality of Cajazeiras-PB, concerning the "births/residence of the mother by the year of birth according to the type of birth.Cajazeiras, PB (2006-2010)", and 
compared to the data from the SMS. In this annual series, respectively, are contained the following percentages for caesareans: 50,$9 ; 59,7 ; 60,9$; 61,2 and 64,9 .

Although this research has not investigated the 2005 DNV (SMS), and the data of the DATASUS are inferior to the primary feeding documents for the SISNAC, it is noticed, according to Table 4, that in the SMS, the data found in 2006 are more elevated in relation to the data informed in the DATASUS, for $2005(42,7 \%)$. In temporal comparison of the SMS data it was found that, from 2006 to 2008, and 2006 to 2010, the percentage differences for more, $9,5 \%$ and $12,9 \%$, respectively, were expressive ${ }^{5}$.

In general, it is noticed an incompatibility between the data extracted from the documents (primary - DNV) and those disclosed in the SUS Department of Informatics. However, in both, the proportion of caesareans, in the investigated municipality, is above the established by the Ministry of Health, and this is contrary to the "Birth Incentive Campaign", not representing a satisfactory health indicator.

In view of this, the OMS reports that there has been an increase in the incidence of caesareans in the entire world, mainly in developing countries. In Latin America, around 800 thousand unnecessary caesareans are performed yearly ${ }^{8}$.

Concerning the Table 5, it has to be highlighted that the uninformed variables are those that are a blank space, to be answered by the person who fills in the DNV. For some variables there is the option "ignored" to be marked with an $X$, if it is the case.

Assuming that the ignored or uninformed data were present in DNV of births that occurred outside the hospital, as they could be completed by a non trained person, it was attempted to clarify this fact. By the SMS findings, from the 3972 analyzed DNV, in only 3 (three) the identification of place of occurrence was not the maternity; of which 2 (two) occurred at domicile and 1 (one) in other establishments. These DNV were not included in those with uninformed or ignored data, in none of the variables. The reality regarding these births outside the hospital was not found in the SINASC, as demonstrated in Table 2.

In the SINASC was not found data related to the mothers' addresses, nor about previous pregnancies. It is understood that these variables cooperate in the understanding of the access to antenatal consultations and health services, as well as in the understanding of the NB weight, from the parity. It is important the awareness of the number of previous gestations, because of the existence of the association between perinatal mortality and the parity. It may be evidenced the risk between the primipara and multipara, in the maternal and neonatal results. The question therefore is: what would be the reason for the existence of these variables in the DNV, if they are not registered in the SINASC?

When analyzing the Table 5, some intriguing factors are noticed which cast doubts on the precision and completeness of the registers of the SINASC, compared to the registers of the SMS. The intriguing factors are:

- Why is the space reserved for the variable type of delivery addressed as ignored?

- Why not inform the mother's age, if the pregnant woman is attended to with an identification document?

- Why mark as ignored the questions related to schooling and the number of antenatal consultations, if the woman remains at the maternity hospital for, the minimum, 24 hours after the birth of the child, sufficient time for this information to be obtained?

- Although these variables may not have been studied in this research, are also found ignored data, in all the investigated years, related to the type of pregnancy (single, double, etc.) and the sex of the NB.

Regarding the uninformed or ignored data in this research, there was also found ignored data; differences are also noticed between the data SMS $x$ SINASC/DATASUS. Thus, in the confrontation of the data in all the tables, incongruence is identified between the two sources of data.

These factors may come to reveal the lack of commitment when filling in the DNV, disregarding essential information. Such result may be justified by the lack of professional training of those who perform the registration of the data in the DNV and or, also, in the collection and register of the data in the electronic system.

The DNV has very important sources of data for the researches in the maternal-infantile area. However, may be responsible for possible significant failures, as the fact of in some cases presenting "ignored", and interfere in the capture and interpretation of the results.

It is necessary to recognize the utility of the data obtained by means of this instrument in the monitoring of health problems. The ambiguity between the presented SMS and DATASUS data compromises the reliability of the SINASC, as the main causes of mistakes in the country's vital statistics in the information systems, are errors in instruments of data collection, as for example the DNV. These errors may be of completeness, accuracy and precision?.

The quality and reliability of the information systems depend directly on the careful execution of each stage of the process, ranging from the control of the forms, their internal flow, collection and electronic register of the data, to its dissemination. In this sense,

So that information systems such as SINASC (...), may be effective in the monitoring and planning of actions in public health, the disseminated information needs to be trustworthy. This is only possible with the correct completion of the collection instruments and the adequate flow of data through the different levels of the system as ordered ${ }^{3: 956}$. 
In relation to schooling, it is information that is not present in the pregnant woman's registers. It is supposed that the ignored items in this variable may be related to a change of the form that the question is written in the declaration, when passed from "level of education"(none, elementary, secondary and superior) "number of years that studied", making it more difficult for those filling it in to understand.

As for the variables related to the duration of the pregnancy and delivery, it is verified that the ignored data was equivalent in both databanks, according to Table 5. However, it is not justified to ignore the type of delivery, if the births occurred in the maternity hospital. To ignore, also, the number of antenatal consultations makes it difficult to evaluate the coverage of the antenatal care, in the health services.

Aiming for quality in the information on live born, the city of São Paulo launched a SINASC Seal, to award the health establishments which fulfill the minimum standards of quality in the completion of the DNV. So, the management responsible for the SINASC in the city of São Paulo, monitors and evaluates the quality of the process and its final product, counting on the participation of the Technical Health Supervisions. Furthermore, periodical technical meetings are carried out, collective and individual professional training ${ }^{10}$.

In another study on secondary data, the Information System on Live Births (SINASC), it was observed that decentralization made in order to enhance the quality of information and its use, provided subsidy for services evaluation and epidemiological studies. Furthermore, the decentralization of the Information System on Live Births enabled the improvement of the completeness of the information in the cities studied, regardless of the size and condition of qualification $^{11}$.

\section{REFERENCES}

1. Secretaria Municipal de Saúde (SP). Manual de preenchimento da Declaração de Nascido Vivo. São Paulo, 2011. Disponível em <http:/ /www.prefeitura.sp.gov.br/cidade/ secretarias/upload/saude/arquivos/ publicacoes/Manual_DN_02fev2011.pdf> Acesso em 6 out $201 \overline{2}$

2. Neves FA, Junges F. Sistema de Informação em Saúde como instrumento de avaliação da saúde da população. Disponível em <http:// www.cpgls.ucg.br/6mostra/artigos/SAUDE/ FL\%C3\% 81VIA\%20DE\%20ASSUN\%C3\% c87\%C3\%830\%20NEVES.pdf> Acesso em 04 set 2012.

3. Nhoncanse GC, Melo DG. Confiabilidade da Declaração de Nascido Vivo como fonte de informação sobre os defeitos congênitos no
In this manner, so that the DNV as a scientific document may provide the improvement of the quality of the assistance to the health of women and children, it is important that the municipal managers are motivated and aware about the use of the data of the live born in the construction of health indicators, which may supply subsidies for the adequate analysis of the health situation, at local, state, regional and national levels.

This research showed that the data contained in the archived DNV in the Epidemiological Surveillance of the municipality of Cajazeiras were not coincident with those disseminated in the SINAS/ DATASUS, related to the municipality, in the temporal series 2006-2010; fact which compromises the reliability of this information system, and casts doubt the precision and completeness of the registers, in face of those of the SMS. So, it is concluded that besides failure in the adequate completion of the DNV at the place of birth, there was failure in the digital typing of the data.

Moreover, comparing the datas contained in DNV (via White) against registered in SINASC is important public health work because it enables comparisons essential to the operation of primary and secondary data in order to better management of public policies12-14.

Finally, so that the DNV's data may subsidize effective actions in the promotion of health, there is a need for training and guidance for the health team, in the attempt to seek a total and correct completion of all the items of the DNV; emphasizing the importance of this document and its integral completion. For this purpose, the importance of motivating the municipal managers in this matter is acknowledged, and to make them aware of the use of the data regarding live births in the construction of health indicators, capable of providing data for the adequate analysis of the health situation, at local level.
Município de São Carlos, São Paulo, Brasil. Ciênc. saúde coletiva [online]. 2012; $17(4)$ :955-63. DOI: $10.1590 /$ S141381232013000800001

4. Instituto Brasileiro de Geografia e Estatística. IBGE cidades@. Cajazeiras - PB: dados básicos. Disponível em <http:// www.ibge.gov.br/cidadesat/painel/ painel. php?codmun $=250370>$. Acesso em 21 set $2012 a$.

5. Ministério da Saúde (BR). Informações de saúde: nascidos vivos - Paraíba - Cajazeiras (2006 a 2010). Disponível em <http:// tabnet.datasus.gov.br/cgi/tabcgi.exe?sinasc/ cnv/nvpb.def> Acesso em 04 set 2012b.

6. Instituto Brasileiro de Geografia e Estatística. IBGE. SIS 2010: Mulheres mais escolarizadas são mães mais tarde e têm menos filhos. 2010a. Disponível em <http://www.ibge. 
gov.br/home/presidencia/noticias/ noticia_visualiza.php?id_noticia $=1717$ \&id_pagina $=1$ > Acesso em 05 set 2012.

7. Ministério da Saúde (BR). DATASUS. Indicadores e Dados Básicos - Brasil - 2010. Indicadores de cobertura. Proporção de partos cesáreas e cobertura de consultas de pré-natal. 2010b Disponível em <http:// tabnet.datasus.gov.br/cgi/idb2010/ matriz.htm? saude $=$ http $\% 3 \mathrm{~A} \% 2 \mathrm{~F} \% 2$ Ftabnet. d a t a s u s.gov. br \% 2 F c g i \% 2 Fidb $2010 \% 2 \mathrm{Fmatriz.htm \& botaook=}$ OK\&obj=http\%3A\%2F\%2Ftabnet.datasus.gov.br \%2Fcgi\%2Fidb2010\%2Fmatriz.htm\#demog> Acesso em 25 set 2012.

8. Giglio MRP, Lamounier JA, Morais Neto OL. Via de parto e risco para mortalidade neonatal em Goiânia no ano 2000. Rev. Saúde Pública. 2005; 39(3):350-7. DOI: 10.1590/S003489102013000100002

9. Martins GA. Sobre confiabilidade e validade. RBGN. São Paulo, 2006 jan/abr; 8(20):1-12. DOI: 10.7819

10. Secretaria Municipal de Saúde (SP). Prefeitura do Município. Coordenação de Epidemiologia e Informação - CEInfo. Sistema de Informação sobre Nascidos Vivos: manual do selo SINASC. São Paulo, 2010. Disponível em <http://www.prefeitura.sp.gov.br/cidade/ secretarias/upload/saude/arquivos/sinasc/ SeloSINASC_manual2010.PDF> Acesso em 6 out 2012.

11. Guimarães EAA, et al. The SINASC descentralization and the completeness of variables on Birth Certificates, in municipalities of Minas Gerais from 1998 to 2005. Journal of Human Growth and Development, 2011; 21(3): 832-840.

12. Figueiredo JL, Vinegoni C, de Abreu LC. Perinatal health and translational medicine. Journal of Human Growth and Development. 2013; 23(2): 125-127.

13. Atrash HK, Carpentier R. The evolving role of public health in the delivery of health care. Journal of Human Growth and Development, 2012; 22(3): 396-399.

14. Leone C. Human Growth: parameters and reflections about growth references. Journal of Human Growth and Development. 2014; 24(1): 7-10. 